\title{
Article \\ Ophelimus bipolaris sp. n. (Hymenoptera, Eulophidae), a New Invasive Eucalyptus Pest and Its Host Plants in China ${ }^{\dagger}$
}

\author{
Hua-Yan Chen ${ }^{1}$, Jie-Min Yao ${ }^{2, *}$, Shao-Bin Huang ${ }^{2}$ and Hong Pang ${ }^{1}$ (D) \\ 1 State Key Laboratory of Biocontrol, School of Life Sciences/School of Ecology, Sun Yat-sen University, \\ Guangzhou 510275, China; chenhuayan@mail.sysu.edu.cn (H.-Y.C.); Lsshpang@mail.sysu.edu.cn (H.P.) \\ 2 Guangdong Eco-Engineering Polytechnic, Guangzhou 510520, China; h3602@126.com \\ * Correspondence: jieminyao@163.com \\ + This published work and the nomenclatural acts it contains have been registered in ZooBank, the online \\ registration system for the ICZN (International Code of Zoological Nomenclature). The LSID (Life Science \\ Identifier) for this publication is: http:/ / zoobank.org/43C58F4B-B721-406A-9293-8DC628B0EB3F.
}

Simple Summary: Eucalyptus species have become one of the most commonly planted trees worldwide, including China. However, the productivity of Eucalyptus plantations has been threatened by the recent increase of invasive insect pests. Gall inducers of the genus Ophelimus (Eulophidae) are among the most important invasive species in Eucalyptus plantations. Based on the combined analysis of biological, morphological and molecular evidence, we here describe a new invasive species, Ophelimus bipolaris sp. n., from China. This wasp induces galls only on the leaf blade surface of four Eucalyptus species. It can complete a life cycle on E. urophylla in approximately 2 months under local climatic conditions in Guangzhou, China.

Citation: Chen, H.-Y.; Yao, J.-M.; Huang, S.-B.; Pang, H. Ophelimus bipolaris sp. n. (Hymenoptera, Eulophidae), a New Invasive Eucalyptus Pest and Its Host Plants in China. Insects 2021, 12, 778. https:// doi.org/10.3390/insects12090778

Academic Editors: Andrew Polaszek and Michael Joseph Sharkey

Received: 14 June 2021

Accepted: 27 August 2021

Published: 30 August 2021

Publisher's Note: MDPI stays neutral with regard to jurisdictional claims in published maps and institutional affiliations.

Copyright: (c) 2021 by the authors. Licensee MDPI, Basel, Switzerland. This article is an open access article distributed under the terms and conditions of the Creative Commons Attribution (CC BY) license (https:/ / creativecommons.org/licenses/by/ $4.0 /)$.
Abstract: Eucalyptus species have become one of the most commonly planted trees worldwide, including China, due to their fast growth and various commercial applications. However, the productivity of Eucalyptus plantations has been threatened by exotic invasive insect pests in recent years. Among these pests, gall inducers of the genus Ophelimus of the Eulophidae family are among the most important invasive species in Eucalyptus plantations. We report here for the first time the presence of a new invasive Eucalyptus gall wasp, Ophelimus bipolaris sp. n., in Guangzhou, China, which also represents the first species of the genus reported from China. The identity of the new species was confirmed by an integrative approach combing biological, morphological and molecular evidence. The new species is described and illustrated. This wasp induces galls only on the leaf blade surface of four Eucalyptus species: E. grandis, E. grandis $\times$ E. urophylla, E. tereticornis and E. urophylla. Our preliminary observation showed that O. bipolaris could complete a life cycle on E. urophylla in approximately 2 months under local climatic conditions $\left(23.5-30^{\circ} \mathrm{C}\right)$. Considering the severe damage it may cause to Eucalyptus production, further investigations of its biology and control are urgently needed in China.

Keywords: Chalcidoidea; DNA barcoding; exotic pest; gall wasp; new species

\section{Introduction}

Most species of the genus Eucalyptus (Myrtaceae) are native to Australia, but have been commonly planted worldwide due to their fast growth and various commercial applications [1]. Eucalypts were first introduced to China sometime before 1894 [2], and the expansion of plantations has dramatically increased in the country since the 1980s [3]. By 2017, eucalypt plantations had been established in all provinces of China south of the Yangtze River, and these plantations amounted to $5.4 \mathrm{M}$ ha [4].

In China, there are about 300 species of phytophagous insects associated with eucalypts [5], including the invasive gall-inducer, Leptocybe invasa Fisher \& La Salle (Hymenoptera, Eulophidae), which was first reported from China in 2007 [6]. Although at least 
one molecular study [7] has suggested that L. invasa in fact comprises two cryptic species, with the female-biased population from China being genetically different from the firstdescribed thelytokous population from the Mediterranean region, no formal taxonomic act has been proposed for the species complex. Nevertheless, Leptocybe invasa is currently the only gall-forming pest of eucalypts recorded in China, and it forms galls (Figure 1A) on the stems, petioles and midribs of leaves of a few Eucalyptus species in the sections Exertaria, Latoanulata and Maidenaria [8]. In April 2021, we found a new form of protruding galls (Figure 1B) on the leaves (never on mid-ribs or branches) of Eucalyptus urophylla S. T. Blake on the campus of Guangdong Eco-Engineering Polytechnic, Guangzhou, China. At the site of the infected trees, we also observed that wasps belong to the family Eulophidae ( $\mathrm{Hy}-$ menoptera) were apparently laying eggs on the young leaves (Figure 2A). On examination of the specimens collected from the leaves and reared from the galls, we found that these wasps are conspecific and belong to the genus Ophelimus Haliday.

The genus Ophelimus is native to Australia and currently contains 53 described species $[9,10]$. Available biological data indicate that species of the genus develop in galls on various species of Eucalyptus and are considered gall inducers [11,12]. Infestations of these gall inducers, especially those invasive species occur outside their native range, can lead to intense gall production on Eucalyptus trees and subsequently, severe defoliation, causing significant economic losses [13-15]. Originally described as Rhicnopeltella eucalyptis Gahan [16] based on female specimens reared from galls on Eucalyptus globulus Labill from New Zealand in 1922, Ophelimus eucalypti (Gahan) was considered the first invasive species reported outside its native Australian origin [13]. By 1987, this species had been recorded inducing galls on the midribs and branches of eucalypt species in the section Maidenaria, and no males of these populations had been observed, and therefore, populations of the species that infected the section Transversaria were later considered the 'Maid' biotype [13]. In 1987, another population identified as O. eucalypti in New Zealand was reared from eucalypt species in the section Transversaria and induced galls only on the leaf blade surface. This latter population was biparental and later was considered as the 'Trans' biotype [13]. Borowiec et al. [9] recently confirmed that O. eucalypti comprises two cryptic lineages ('Maid and 'Trans') based on the host plant, reproduction mode and morphological and molecular (28S) differences. Ophelimus eucalypti was erroneously reported in Europe [9,14], but by 2019 , both lineages of O. eucalypti were only listed in New Zealand. Recently, the first report of O. eucalypti outside of New Zealand was in Sumatra, Indonesia, where it had caused serious damage to E. urophylla and hybrids of the species with Eucalyptus grandis W. Hill, but the lineage has not been determined [15]. However, currently the most widely distributed invader is Ophelimus maskelli (Ashmead), which was first described as Pteroptrix maskelli from New Zealand by Ashmead in 1900 and was transferred to the genus Ophelimus by Bouček [11]. Outside its native range, O. maskelli has been reported from the Mediterranean Basin, Southeast Asia, South Africa and North America (see references in Borowiec et al. [9] and Dittrich-Schröder et al. [15]). Ophelimus maskelli is a thelytokous (only reproduce females) species and induces blister-like galls near the petiole on the leaf blade of Eucalyptus species. Uncontrolled populations of these wasps can cause severe leaf damage and almost complete defoliation of mature trees in some cases [14,17]. Fourteen host species have been recorded for O. maskelli, with Eucalyptus camaldulensis Dehnhardt and Eucalyptus tereticornis Smith being economically important and particularly suitable species [14]. Recently, two species, Ophelimus mediterraneus Borowiec \& Burks and Ophelimus migdanorum Molina-Mercader were newly described from the Mediterranean Europe [9] and Chile [10], respectively. Ophelimus mediterraneus is also a thelytokous species and induces galls on the upper surface of the leaves on Eucalyptus species from the Maidenaria section, such as Eucalyptus globulus Labill and Eucalyptus gunii J. D. Hook [9]. While O. migdanorum is a biparental species and induces galls on stems, petioles, laminae and leaf venations of E. globulus and Eucalyptus camaldulensis Dehnh [10]. 


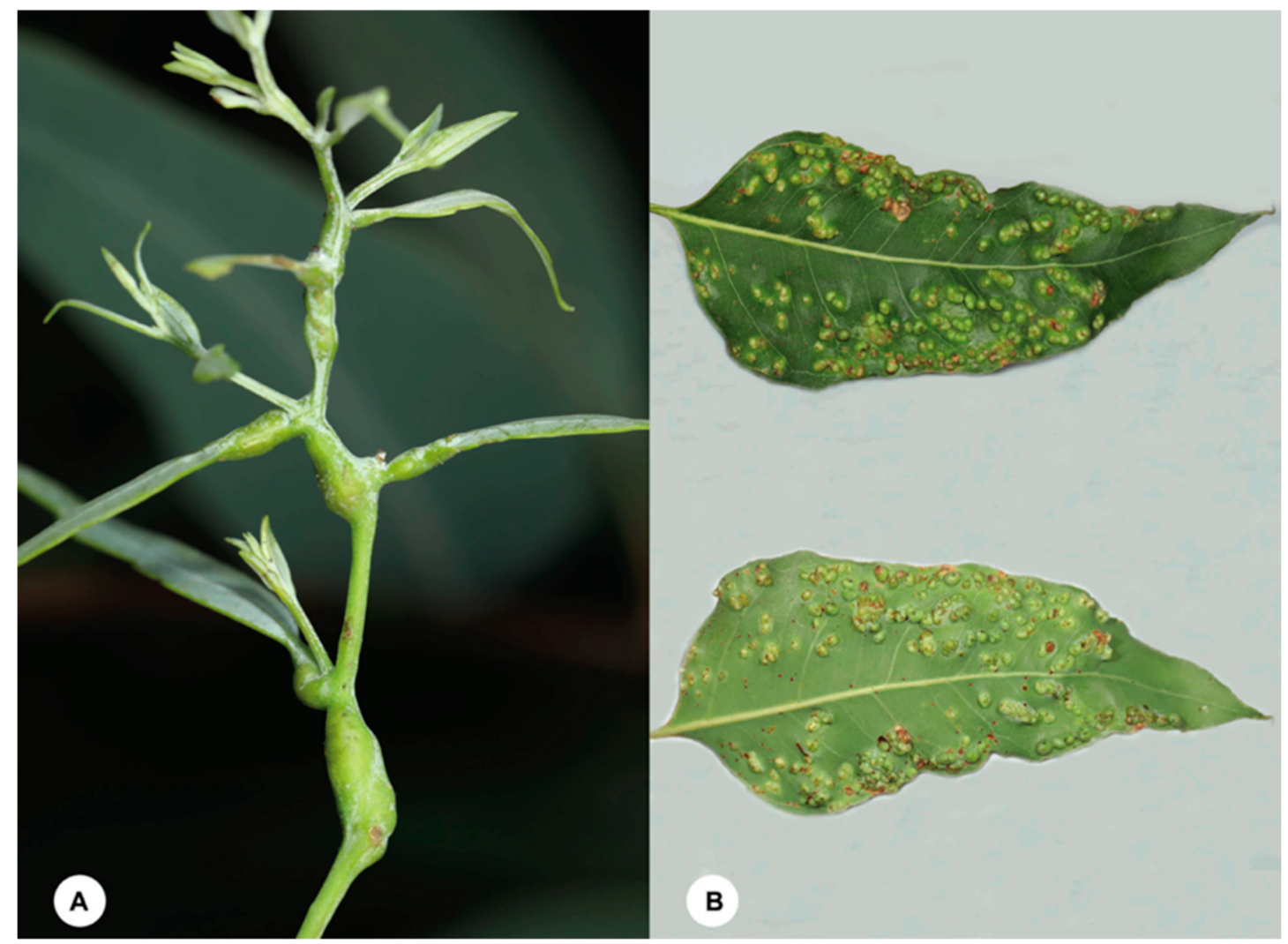

Figure 1. (A) Galls of Leptocybe invasa Fisher \& La Salle on Eucalyptus exserta F. Muell. (B) Galls of Ophelimus bipolaris sp. n. on Eucalyptus urophylla S. T. Blake. (All photographed in Guangzhou, China).

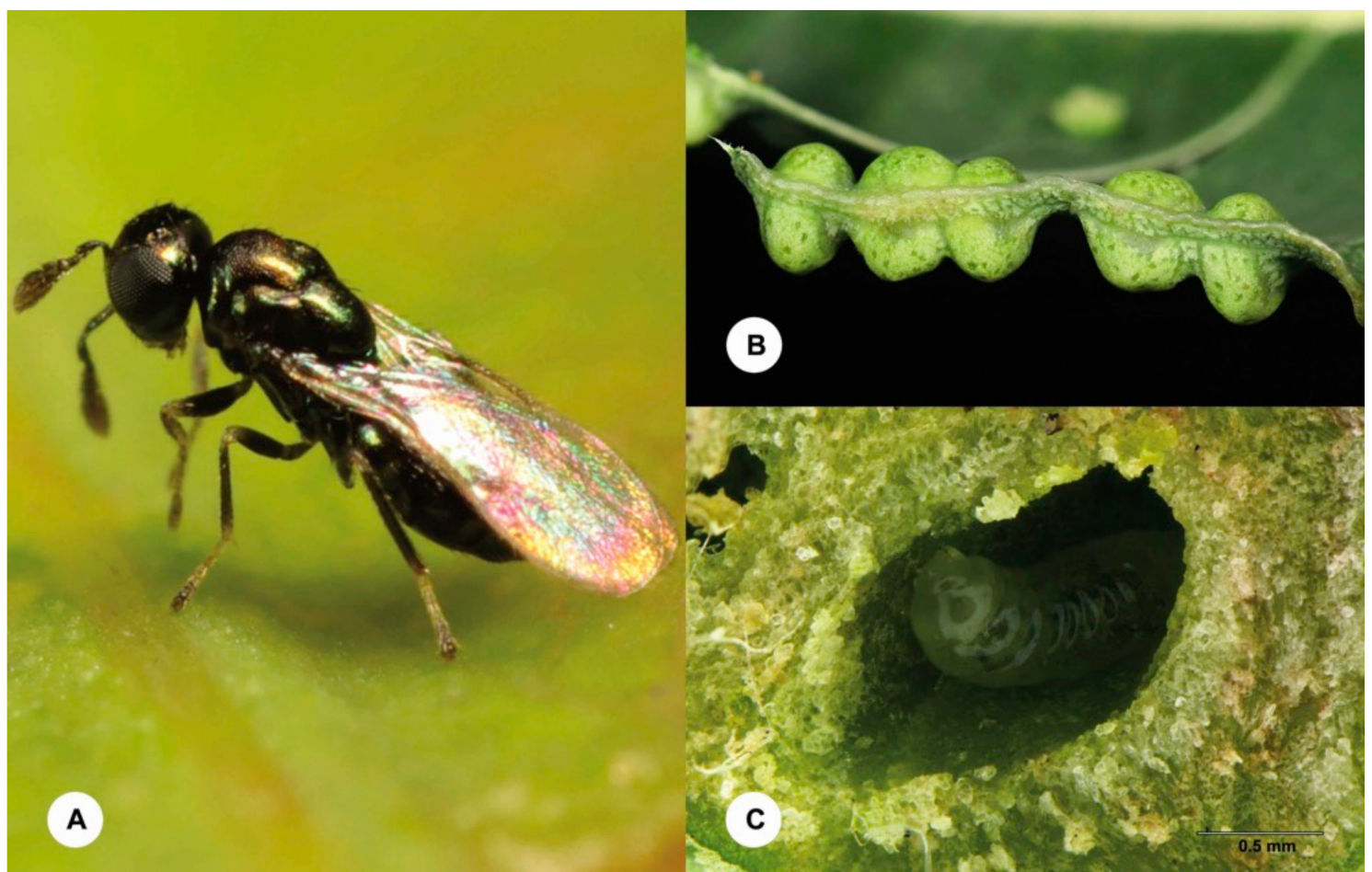

Figure 2. (A) A female of Ophelimus bipolaris sp. n. on the young leaf of Eucalyptus urophylla S. T. Blake. (B) Mature galls on the leaf edge of E. urophylla, lateral view (C) A mature gall on the leaf of E. urophylla cut open to show the larva of Ophelimus bipolaris sp. n. 
Considering the economic importance of Ophelimus species to the production of Eucalyptus trees, in this study, we aim to investigate the identity of the Ophelimus species we just found in Guangzhou, China, using an integrative taxonomic approach combining biological, morphological and molecular information.

\section{Materials and Methods}

\subsection{Insect Sampling}

The initial survey was conducted between April and July 2021 in a small E. urophylla plantation on the campus of Guangdong Eco-Engineering Polytechnic (GEEP), Guangzhou, China. To investigate the host range of the wasp, additional surveys were conducted between early June and late July at three other localities in Guangzhou (Table 1). Wasps on the leaves of Eucalyptus trees were collected and preserved in 95\% ethanol. Mature leaves with large galls of each infected Eucalyptus species were collected, labeled and placed in small plastic bags at the laboratory of Sun Yat-sen University, Guangzhou, China. Emergences were checked daily, and all emerged adult wasps were collected in 95\% ethanol to allow for further molecular and morphological study. Voucher specimens are deposited in the Museum of Biology at Sun Yat-sen University (SYSBM), Guangzhou, China. During the initial survey in April at the plantation of GEEP, young leaves of E. urophylla were observed being attacked by the wasps. Such leaves were recorded and left on the tree until they were covered with large mature galls and then were collected in plastic bags as described above.

Table 1. Details of surveyed localities and Eucalyptus species.

\begin{tabular}{|c|c|c|}
\hline Locality & Coordinates & Eucalyptus Species \\
\hline $\begin{array}{l}\text { Guangdong Eco-Engineering } \\
\text { Polytechnic (GEEP) }\end{array}$ & $23^{\circ} 11^{\prime} 58^{\prime \prime} \mathrm{N} 113^{\circ} 22^{\prime} 35^{\prime \prime} \mathrm{E}$ & E. urophylla* \\
\hline Xiaoguwei Island (XI) & $23^{\circ} 4^{\prime} 0^{\prime \prime} \mathrm{N} 113^{\circ} 22^{\prime} 41^{\prime \prime} \mathrm{E}$ & $\begin{array}{c}\text { E. urophylla } *, \text { E. grandis } \times \\
\text { E. urophylla } * \text {, E. citriodora, } \\
\text { E. exserta }\end{array}$ \\
\hline $\begin{array}{l}\text { South China Botanical Garden } \\
\text { (SCBG) }\end{array}$ & $23^{\circ} 10^{\prime} 52^{\prime \prime} \mathrm{N} 113^{\circ} 21^{\prime} 28^{\prime \prime} \mathrm{E}$ & $\begin{array}{c}\text { E. tereticornis }{ }^{*}, \text { E. citriodora, } \\
\text { E. exserta }\end{array}$ \\
\hline Huolushan Forest Park (HFP) & $23^{\circ} 10^{\prime} 39^{\prime \prime} \mathrm{N} 113^{\circ} 22^{\prime} 56^{\prime \prime} \mathrm{E}$ & $\begin{array}{l}\text { E. urophylla*, E. grandis *, } \\
\text { E. exserta }\end{array}$ \\
\hline
\end{tabular}

\subsection{Species Identification}

Morphological terminology generally follows Gibson et al. [18]. The systematics and taxonomy of Ophelimus are poorly studied [14]. However, some characters, especially the number of setae on the submarginal vein of fore wings, are thought to be diagnostically valuable [14]. Recently, Borowiec et al. [9] provided a key for some Ophelimus species of agricultural interest. To supplement morphological identifications, two molecular markers, mitochondrial DNA (mtDNA) cytochrome c oxidase 1 (COI) and nuclear 28S rRNA D1-2 (28S) were sequenced for molecular species delimitation. Genomic DNA was extracted from 13 adults and two larvae dissected from the gall using a nondestructive method as described in Taekul et al. [19]. Detailed information about the sequenced specimens used in this study is given in Table 2. Polymerase chain reaction (PCR) amplifications of the two DNA fragments were performed using Tks Gflex DNA Polymerase (Takara, Shiga, Japan) and conducted in a T100 Thermal Cycler (Bio-Rad). The primer pairs LCO1490/HCO2198 [20] and D2-3551F/D2-4057R [21] were used for COI and 28S, respectively. Thermocycling conditions were: an initial denaturing step at $94{ }^{\circ} \mathrm{C}$ for $5 \mathrm{~min}$, followed by 35 cycles of $94{ }^{\circ} \mathrm{C}$ for $30 \mathrm{~s}, 50{ }^{\circ} \mathrm{C}$ for $30 \mathrm{~s}, 72{ }^{\circ} \mathrm{C}$ for $30 \mathrm{~s}$ and an additional extension at $72{ }^{\circ} \mathrm{C}$ for $5 \mathrm{~min}$. Amplicons were directly sequenced in both directions with forward and reverse primers on an Applied Biosysttems (ABI) 3730XL (Applied Biosystems, Foster City, CA, USA) by Guangzhou Tianyi Huiyuan Gene Technology Co., Ltd. (Guangzhou, China). 
Chromatograms were assembled with Geneious 11.0.3. All the amplified sequences were deposited into GenBank (Table 2).

Table 2. Details of specimens sequenced and accession numbers.

\begin{tabular}{|c|c|c|c|c|c|c|c|}
\hline \multirow{2}{*}{ Code } & \multirow{2}{*}{ Locality } & \multirow{2}{*}{ Host Plant } & \multirow{2}{*}{ Stage } & \multirow{2}{*}{ Sex } & \multirow{2}{*}{$\begin{array}{c}\text { Submarginal } \\
\text { Vein Setae }\end{array}$} & \multicolumn{2}{|c|}{ GenBank Accession Number } \\
\hline & & & & & & COI & $28 S$ \\
\hline HC739 & GEEP & E. urophylla & adult & female & 4 & MZ348610 & MZ348616 \\
\hline HC740 & GEEP & E. urophylla & larva & NA & NA & MZ348611 & MZ348617 \\
\hline HC745 & GEEP & E. urophylla & adult & male & 3 & MZ348612 & MZ348618 \\
\hline HC746 & GEEP & E. urophylla & adult & male & 4 & MZ348613 & MZ348619 \\
\hline $\mathrm{HC} 747$ & GEEP & E. urophylla & adult & female & 5 & MZ348614 & MZ348620 \\
\hline HC785 & XI & E. grandis $\times$ E. urophylla & adult & female & 4 & MZ605326 & MZ605354 \\
\hline HC786 & XI & E. grandis $\times$ E. urophylla & larva & NA & NA & MZ605327 & MZ605355 \\
\hline HC787 & XI & E. urophylla & adult & female & 5 & MZ605328 & MZ605356 \\
\hline HC788 & XI & E. urophylla & adult & female & 4 & MZ605329 & MZ605357 \\
\hline HC789 & HFP & E. grandis & adult & female & 4 & MZ605330 & MZ605358 \\
\hline HC790 & HFP & E. grandis & adult & female & 3 & MZ605331 & MZ605359 \\
\hline HC791 & HFP & E. urophylla & adult & female & 5 & MZ605332 & MZ605360 \\
\hline HC792 & HFP & E. urophylla & adult & female & 4 & MZ605333 & MZ605361 \\
\hline HC793 & XI & E. urophylla & adult & male & 3 & MZ605334 & MZ605362 \\
\hline HC794 & SCBG & E. tereticornis & adult & female & 4 & MZ605335 & MZ605363 \\
\hline
\end{tabular}

All sequences were blasted in the BOLD (Barcode of Life Database, http://www. barcod-inglife.org/index.php/IDS_OpenIdEngine, only for COI) and GenBank. The sequences generated in this study along with representatives generated by Molina-Mercader et al. [10] and Borowiec et al. [9] were aligned using MAFFT v7.470 by the Q-INS-I strategy for $28 \mathrm{~S}$ and G-INS-I strategy for COI [22]. After removing the identical sequences, the alignments were then analyzed using RAxML as implemented in Geneious 11.0.3. Sequences of Closterocerus chamaeleon (Girault) (Hymenoptera: Eulophidae) were used as outgroups to root the trees as used by Borowiec et al. [9].

\subsection{Photography}

Images of live specimens and trees were taken with a Canon 5D Mark III (Tokyo, Japan) camera with a $100 \mathrm{~mm}$ macro lens. Images of mounted specimens were produced using a Nikon SMZ25 microscope (Melville, NY, USA) with a Nikon DS-Ri 2 (Melville, NY, USA) digital camera system. Images of the type specimen of O. eucalypti were provided by the National Museum of Natural History (NMNH), Smithsonian Institution, Washington, DC, USA. Scanning electron micrographs were produced using a Phenom Pro Desktop SEM and single montage images were generated from image stacks in the program Helicon. Images were post-processed with Adobe Photoshop CS6 Extended.

\section{Results}

Of the four sampled localities, six Eucalyptus species or hybrid species were surveyed and four of them were infected by Ophelimus wasps: E. grandis, E. grandis $\times$ E. urophylla, E. tereticornis and E. urophylla (Table 1). Galls were only found on the leaf blade surface of all the four infected Eucalyptus species. Mature galls (Figure 2B) are 2-3 $\mathrm{mm}$ in diameter and protrude 1-2 $\mathrm{mm}$ on each side of the leaf. Each gall contains a single larva (Figure 2C) but eggs tend to be laid close together on a leaf and develop patches of tightly packed galls. In severe cases, the entire leaf is totally covered with galls. Galls change from green to red, then to brown. A circular exit hole is left on the gall as the adult wasp emerges. In this study, a total of 1244 Ophelimus specimens were collected, and $97.2 \%$ were females. Detailed information about the collected specimens is given in Table S1.

During the survey, at the end of April at the GEEP plantation, young leaves of the upper shoots of five two-year old trees at the infested site showed no sign of galls, but by the end of May, almost each of those leaves was covered with numerous green or red 
galls, and a few adult wasps emerged in mid-June. According to the temperature records provided by the China Meteorological Data Service Center, the average temperatures of Guangzhou from April to July ranged from $23.5^{\circ} \mathrm{C}$ to $30^{\circ} \mathrm{C}$ (Figure S1). Although biological studies of this wasp species on the host plants are still on going, our preliminary observation showed that the duration of its life cycle is approximately 2 months, at least so on E. urophylla in Guangzhou.

Both $28 \mathrm{~S}$ and COI genes were successfully sequenced from all the 15 specimens (13 adults + 2 larvae). All the sequences of $28 S$ ( $605 \mathrm{bp}$ ) were identical to each other and showed $99.3-99.5 \%$ identity to the O. eucalypti 'Trans' biotype and $98.1 \%$ to the O. eucalypti 'Maid' biotype in the GenBank database (Table S2). Phylogenetic analysis based on $28 \mathrm{~S}$ sequences generated from this study together with those used by Borowiec et al. [9] showed that the Chinese Ophelimus species is sister to the O. eucalypti 'Trans' biotype (Figure 3), which together form a clade clearly separated from other species. The 15 sequences of $C O I$ (660-678 bp) were also mostly identical, with only one sequence (MZ348610) differed by two nucleotides. These COI sequences do not show a high match with sequences in both the BOLD and GenBank databases. The closest match is Ophelimus migdanorum MolinaMercader, with $92.28 \%$ identical pairs of bases (Table S3). When analyzed with the COI sequences of $O$. maskelli (Ashmead), O. mediterraneus and O. migdanorum, the two unique COI sequences of the Chinese Ophelimus species formed a clade sister to O. migdanorum but with a low support (Figure 4). While there is no COI sequence of either biotype of O. eucalypti in the BOLD and GenBank databases, the $28 S$ sequences well suggest that the Chinese Ophelimus species might be conspecific to the O. eucalypti 'Trans' biotype or a closely related species. Considering that the two biotypes of $O$. eucalypti are most likely two distinct species, as confirmed by Borowiec et al. [9] using molecular, morphological (number of submarginal vein setae) and ecological (host range) data, the Ophelimus species we found in Guangzhou should represent a distinct species different from O. eucalypti sensu Gahan.

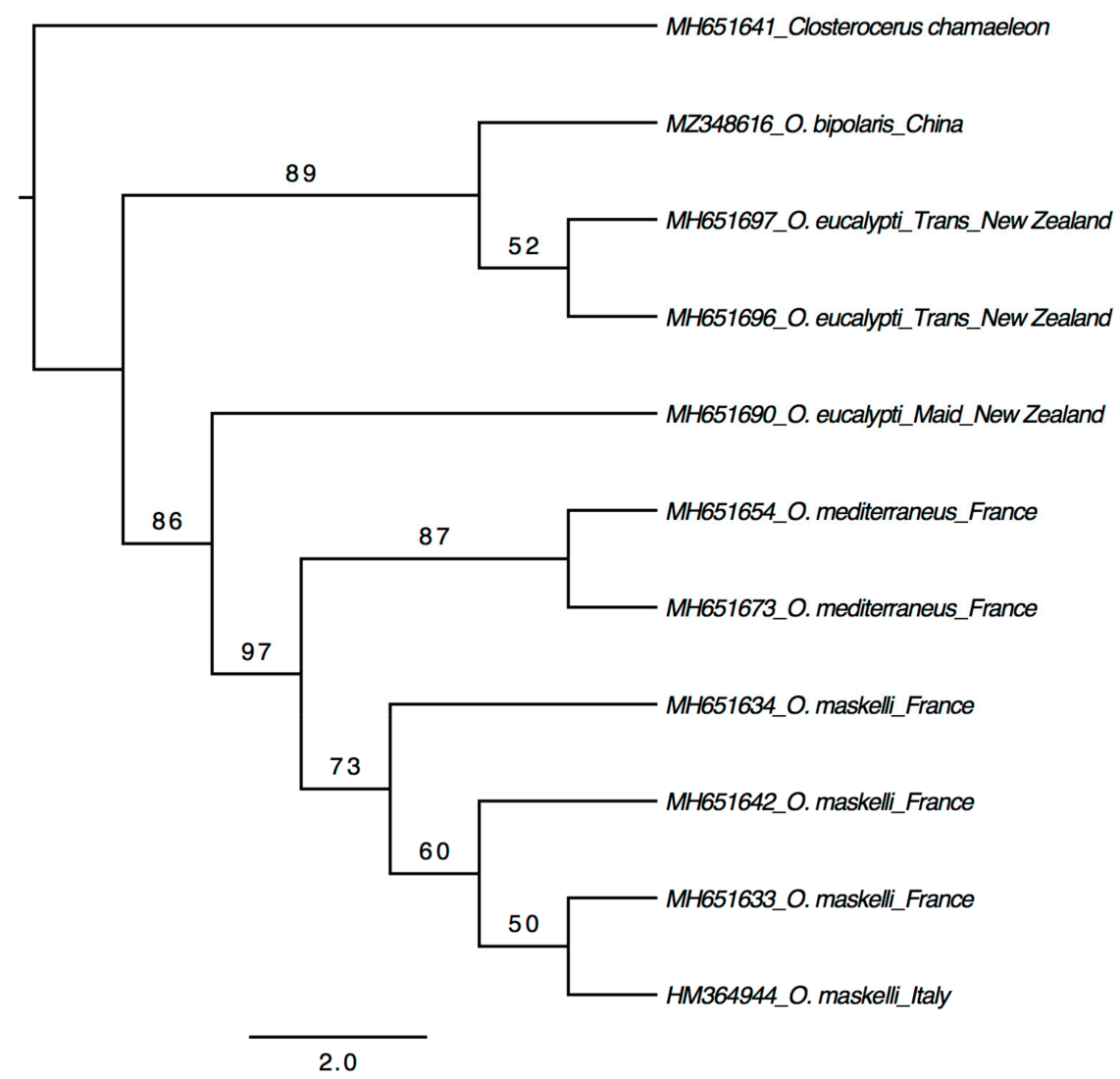

Figure 3. Maximum likelihood tree based on $28 S$. 


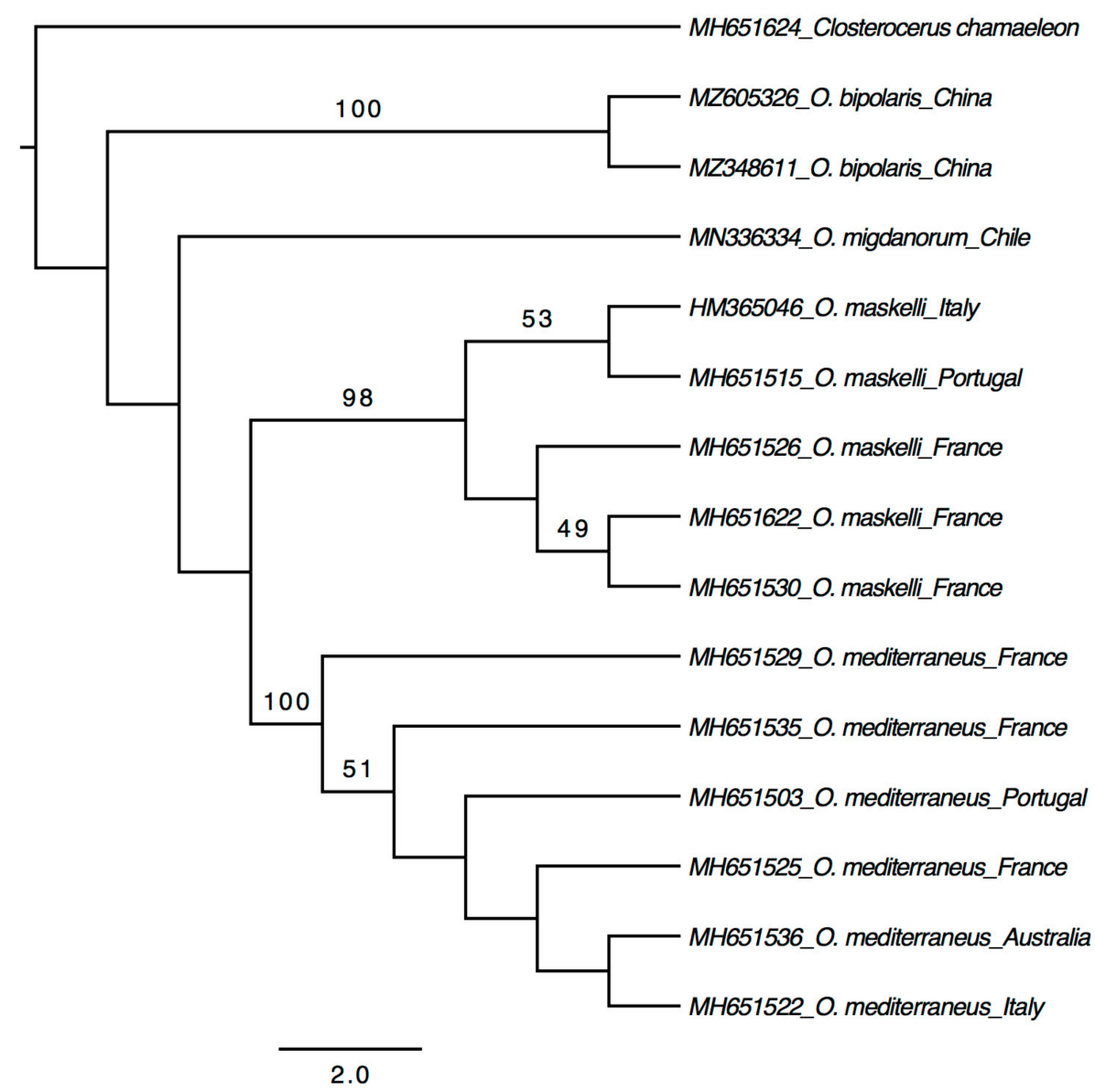

Figure 4. Maximum likelihood tree based on COI, only values $>50$ for bootstrap are labeled.

Further examination indicates that the wasps we collected in Guangzhou are morphologically identical. By comparing the holotype of O. eucalypti (based on images provided by NMNH, Figure S2) and the original description of the species provided by Gahan [16], as well as running the key compiled by Borowiec et al. [9], we conclude that the Ophelimus species we found belong to an undescribed species and we here describe it as new to science below.

Ophelimus bipolaris Chen \& Yao, sp. $n$.

Material examined: Holotype, female, CHINA: Guangdong, Guangzhou, campus of Guangdong Eco-Engineering Polytechnic, $23^{\circ} 11^{\prime} 58^{\prime \prime} \mathrm{N} 113^{\circ} 22^{\prime} 35^{\prime \prime} \mathrm{E}$, reared from galls on the leaf of Eucalyptus urophylla S. T. Blake, 24.iv.2021, Huayan Chen, HC739 (deposited in SYSBM) (GenBank accession numbers: COI, MZ348610; 28S, MZ348616). Paratypes: (116 females, 12 males) CHINA: 50 females, 10 males, same data as holotype (SYSBM); 20 females, 2 males, Guangdong, Guangzhou, Xiaoguwei Island, $23^{\circ} 4^{\prime} 0^{\prime \prime} \mathrm{N} 113^{\circ} 22^{\prime} 41^{\prime \prime} \mathrm{E}$, reared from galls on the leaf of E. urophylla, 11.vii.2021, Huayan Chen (SYSBM); 20 females, Guangdong, Guangzhou, Xiaoguwei Island, $23^{\circ} 4^{\prime} 0^{\prime \prime} \mathrm{N} 113^{\circ} 22^{\prime} 41^{\prime \prime} \mathrm{E}$, reared from galls on the leaf of E. grandis $\times$ urophylla, 11.vii.2021, Huayan Chen (SYSBM); 4 females, Guangdong, Guangzhou, South China Botanical Garden, $23^{\circ} 10^{\prime} 52^{\prime \prime}$ N $113^{\circ} 21^{\prime} 28^{\prime \prime}$ E, reared from galls on the leaf of E. tereticornis, 13.vii.2021, Huayan Chen (SYSBM); 15 females, Guangdong, Guangzhou, Huolushan Forest Park, $23^{\circ} 10^{\prime} 39^{\prime \prime}$ N $113^{\circ} 22^{\prime} 56^{\prime \prime}$ E, reared from galls on the leaf of E. grandis, 13.vii.2021, Huayan Chen (SYSBM); 7 females, Guangdong, Guangzhou, Huolushan Forest Park, $23^{\circ} 10^{\prime} 39^{\prime \prime} \mathrm{N} 113^{\circ} 22^{\prime} 56^{\prime \prime}$ E, reared from galls on the leaf of E. urophylla, 13.vii.2021, Huayan Chen (SYSBM).

Etymology: The name bipolaris refers to the gall induced by this species that protrudes from both sides of the leaves of the host plants. 
Diagnosis. Submarginal vein of fore wing with 3-5 dorsal setae. Body mainly reticulate. Mesoscutal midlobe with 5 pairs of long setae. Propodeum medially longer than metascutellum. Marginal vein about $1.8 \times$ length of stigmal vein. Postmarginal vein distinctly shorter than stigmal vein. The new species is similar to other well-known Ophelimus invasive species. The differences between the new species and other four Ophelimus species of agriculture interest are summarized in Table 3.

Table 3. Comparison of Ophelimus bipolaris with other known Ophelimus species.

\begin{tabular}{|c|c|c|c|c|c|c|}
\hline & O. bipolaris & $\begin{array}{l}\text { O. eucalypti } \\
\text { 'Maid.' }\end{array}$ & $\begin{array}{l}\text { O. eucalypti } \\
\text { 'Trans.' }\end{array}$ & O. maskelli & O. mediterraneus & O. migdnorum \\
\hline Head color & $\begin{array}{l}\text { Brown with } \\
\text { metallic green }\end{array}$ & $\begin{array}{l}\text { Mainly black, } \\
\text { frons faintly } \\
\text { tinged with } \\
\text { metallic green }\end{array}$ & $\begin{array}{l}\text { Mainly black, } \\
\text { frons faintly } \\
\text { tinged with } \\
\text { metallic green }\end{array}$ & $\begin{array}{l}\text { Brown with } \\
\text { metallic green }\end{array}$ & $\begin{array}{l}\text { Brown with } \\
\text { metallic green }\end{array}$ & $\begin{array}{l}\text { Brown with } \\
\text { metallic green }\end{array}$ \\
\hline Mesosoma color & $\begin{array}{l}\text { Brown with } \\
\text { metallic green }\end{array}$ & $\begin{array}{l}\text { Mainly black, } \\
\text { dorsal mesosoma } \\
\text { faintly tinged } \\
\text { with purplish }\end{array}$ & $\begin{array}{l}\text { Mainly black, } \\
\text { dorsal mesosoma } \\
\text { faintly tinged } \\
\text { with purplish }\end{array}$ & $\begin{array}{l}\text { Brown with } \\
\text { metallic green }\end{array}$ & $\begin{array}{l}\text { Brown with } \\
\text { metallic green }\end{array}$ & $\begin{array}{l}\text { Brown with } \\
\text { metallic green }\end{array}$ \\
\hline Body length & $\begin{array}{c}\text { Female: } \\
1.1-1.8 \mathrm{~mm} \text {; male: } \\
1.0-1.2 \mathrm{~mm}\end{array}$ & $\begin{array}{l}\text { Female: } \\
2.0-2.5 \mathrm{~mm}\end{array}$ & $\begin{array}{l}\text { Female: } \\
\text { 2.0-2.5 mm; } \\
\text { male: ? }\end{array}$ & $\begin{array}{l}\text { Female: } \\
0.8-1.1 \mathrm{~mm}\end{array}$ & $\begin{array}{l}\text { Female: } \\
0.8-1.0 \mathrm{~mm}\end{array}$ & $\begin{array}{c}\text { Female: } \\
0.7-1.4 \mathrm{~mm} \text {; male: } \\
0.7-1.4 \mathrm{~mm}\end{array}$ \\
\hline $\begin{array}{l}\text { No. of setae on } \\
\text { submarginal vein }\end{array}$ & $3-5$ & $2-4$ & $\geq 5$ & 1 & $2-4$ & $1-3$ \\
\hline $\begin{array}{c}\text { Marginal } \\
\text { vein/Stigmal vein }\end{array}$ & About $1.8 \times$ & About $2 \times$ & About $2 \times ?$ & About $0.7 \times$ & About $0.7 \times$ & $0.7-0.8 \times$ \\
\hline $\begin{array}{c}\text { Postmarginal } \\
\text { vein/Stigmal vein }\end{array}$ & $<0.5 \times$ & $>1 \times$ & $>1 \times ?$ & $>2 \times$ & $>1 \times$ & $>3 \times$ \\
\hline $\begin{array}{l}\text { No. of setae on } \\
\text { mesoscutal } \\
\text { midlobe }\end{array}$ & 5 pairs & 6 pairs & 6 pairs? & 2 pairs & 2 pairs & Unknown \\
\hline $\begin{array}{l}\text { Propodeum vs. } \\
\text { Metascutellum }\end{array}$ & Distinctly longer & Subequal & Subequal? & Subequal & Subequal & Unknown \\
\hline Hosts & $\begin{array}{c}\text { E. grandis, } \\
\text { E. grandis } \times \\
\text { urophylla, } \\
\text { E. tereticornis and } \\
\text { E. urophylla }\end{array}$ & $\begin{array}{c}\text { Eucalyptu from } \\
\text { section Maidenaria }\end{array}$ & $\begin{array}{l}\text { Eucalyptu from } \\
\text { section } \\
\text { Transversaria }\end{array}$ & $\begin{array}{c}\text { Eucalyptu from } 3 \\
\text { sections: } \\
\text { Exsertaria, } \\
\text { Latoangulata and } \\
\text { Maidenaria }\end{array}$ & $\begin{array}{c}\text { Eucalyptu from } \\
\text { section Maidenaria }\end{array}$ & $\begin{array}{l}\text { E. globulus, } \\
\text { E. camaldulensis }\end{array}$ \\
\hline Galls & $\begin{array}{l}\text { Only on leaf } \\
\text { blade, round and } \\
\text { smooth, green } \\
\text { then to reddish } \\
\text { galls visible on } \\
\text { both sides of the } \\
\text { leaves }\end{array}$ & $\begin{array}{l}\text { On leaf midribs, } \\
\text { leaf blade and } \\
\text { shoot axes, round } \\
\text { and smooth, } \\
\text { green then to } \\
\text { reddish galls }\end{array}$ & $\begin{array}{c}\text { Only on leaf } \\
\text { blade, females } \\
\text { induce circular, } \\
\text { protruding galls, } \\
\text { males induce pit } \\
\text { galls }\end{array}$ & $\begin{array}{l}\text { Only on leaf } \\
\text { blade, round and } \\
\text { smooth, green } \\
\text { then to reddish } \\
\text { galls visible on } \\
\text { both sides of the } \\
\text { leaves }\end{array}$ & $\begin{array}{l}\text { Only on leaf } \\
\text { blade, ellipsoidal, } \\
\text { conical shaped, } \\
\text { brown coloured } \\
\text { with rough and } \\
\text { racked surface on } \\
\text { just the upper } \\
\text { side of the leaves }\end{array}$ & $\begin{array}{l}\text { On leaf blade, } \\
\text { midrib, secondary } \\
\text { rib, petiole, and } \\
\text { twigs, amorphous }\end{array}$ \\
\hline
\end{tabular}

Note: “?” denotes uncertain because the O. eucalypti 'Trans.' biotype has been reported indistinguishable from O. eucalypti 'Maid.' biotype but never been clearly described. Summarized data of body measurements and best ratios of O. bipolaris see Table S4. Data of O. eucalypti, O. maskelli, O. mediterraneus and O. migdnorum are from published literatures $[9,10,13,14,16,23]$.

Description: Female (Figure 5). Body length 1.1-1.8 mm.

Colour: Head and body brown with variable metallic green and orange luster, metasoma darker dorsally. Antenna brown. Coxae brown with metallic green luster, first three tarsomeres pale brown, remainders of legs dark brown to brown. Wings hyaline, with veins grayish black.

Head: Reticulate, except scrobal depression and clypeus smooth. Vertex, gena, lateral frons and ventral half of face with sparse long setae. Ocelli in a low triangle, widely separated, the posterior ocelli separated from the eye margin by about the diameter of an ocellus. Eye with short setae that are visible at high magnification. Malar sulcus shallow 
but visible. Clypeus small, lateral margin hardly distinguishable. Anterior tentorial pit present. Mandible bidentate, ventral tooth much larger than dorsal tooth.

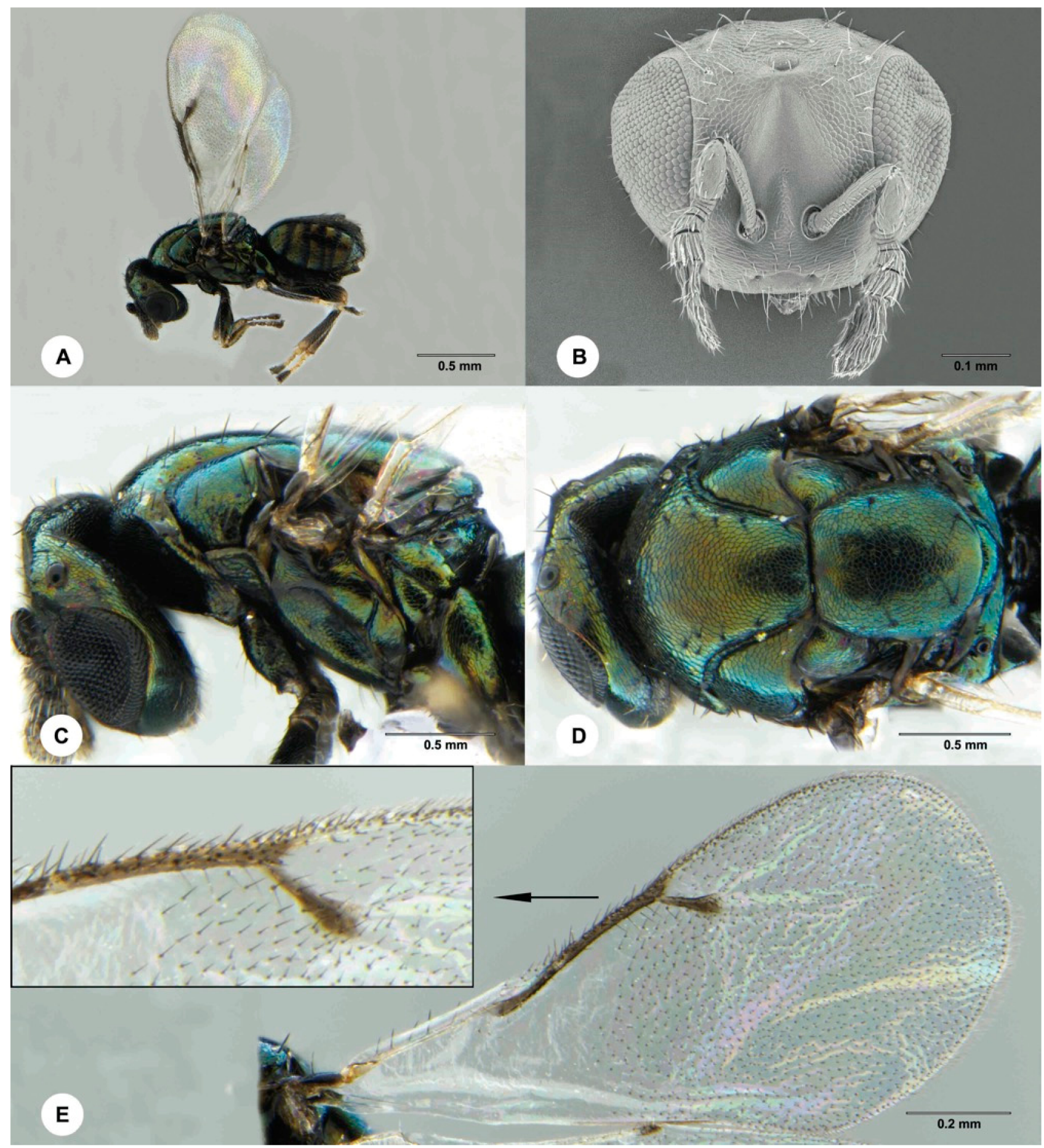

Figure 5. Ophelimus bipolaris sp. n., female (A) Habitus, lateral view (B) Head, anterior view (C) Head and mesosoma, lateral view (D) Head and mesosoma, dorsal view (E) Fore wing.

Antenna: Pedicel slight shorter then funicle. First four flagellomeres anellifrom, the last also transverse but much larger and bearing multiporous plate sensilla. Club longer than the other flagellmeres combined, ovate, with three distinct clavomeres, the apical one bearing a long terminal seta. 
Mesosoma: Entirely reticulate. Mesoscutum slightly longer than mesoscutellum. Mesoscutal midlobe with 5 pairs of long setae, anterior 2 pairs of setae relatively shorter. Notaulus deep and complete, sharply curved outward anteriorly. Mesoscutellum slightly longer than broad, with 2 pairs of long setae. Mesoscutellar rim not carinate, but slightly overhanging metascutellum. Axillular groove present. Metascutellum short, not overhanging propodeum. Propodeum medially longer than metascutellum, posterior margin excavated medially, lateral propodeal area with 3-5 setae.

Wings: Fore wing about as long as body, about twice as long as broad. Submarginal vein with 3-5 dorsal setae. Marginal vein about $1.8 \times$ length of stigmal vein. Postmarginal vein distinctly shorter than stigmal vein, tapering gradually from the base until lost in the margin of wing.

Legs: Coxae reticulate. Femora and tibia imbricate. Tibial spur formula 1-1-1. Mesotibial spur about as long as the first two mid tarsomeres combined. Hind femur slightly thickened. Hind tibia densely setose.

Metasoma: Subspherical, about as long as mesosoma or slightly shorter, apex not pointed. First tergum the longest, second to sixth terga subequal, each about half length of the first tergum. Ovipositor short, not exserted. Hypopygium reaching about $0.3 \times$ length of metasoma. All terga reticulate.

Male (Figure 6): Body length 1.0-1.2 mm. Similar to female, except: submarginal vein of fore wing with 3-4 setae; antennal club relatively slender and covered with fewer multiporous plate sensilla (Figure 7); genitalia extruded.

Hosts: E. grandis, E. grandis $\times$ E. urophylla, E. tereticornis and E. urophylla.

Distribution: China (Guangdong).

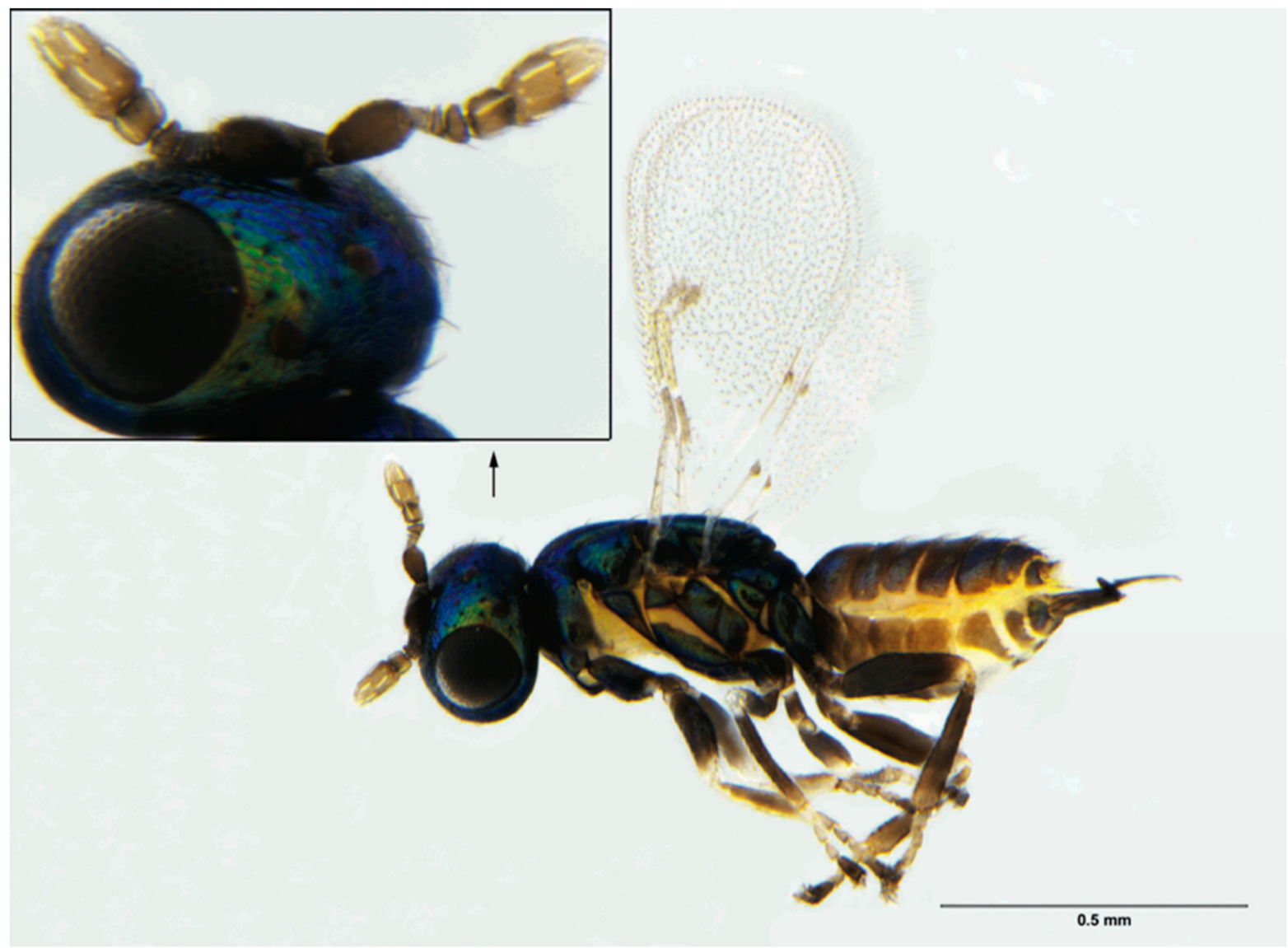

Figure 6. Ophelimus bipolaris sp. n., male, habitus with head in the excerpt, lateral view. 


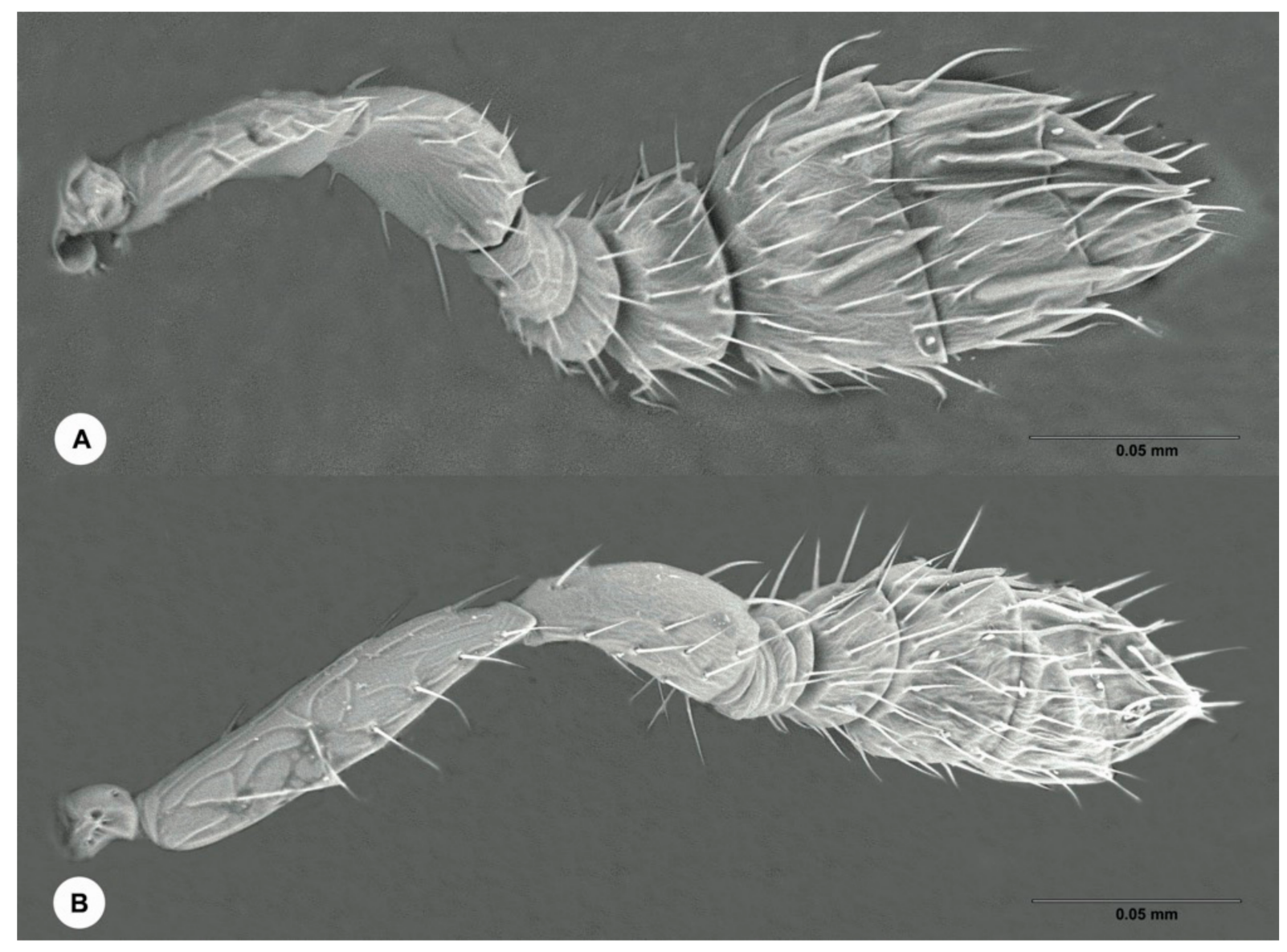

Figure 7. Ophelimus bipolaris sp. n. Antenna (A) Female (B) Male.

\section{Discussion}

There are 53 described species of Ophelimus and the genus is poorly studied and needs a thorough taxonomic revision $[9,14]$. Therefore, synonymies are likely to be detected in future. It is possible that $O$. bipolaris was described previously under another name. However, considering the fact that the descriptions of most of the old species are always poor and the types are in very bad conditions [9], the task of attempting to attain the holotype of each species to rule out that possible species' identity would severely delay or even prohibit the execution of this study. The combined analyses of biological, molecular and morphological data (Table 3) presented here should permit the unequivocal identification of O. bipolaris sp. $\mathrm{n}$.

Ophelimus bipolaris induces protruding galls on the leaves of E. grandis, E. grandis $\times$ urophylla, E. tereticornis and E. urophylla. The galls induced by O. bipolaris are most similar to those induced by the O. eucalypti 'Trans' biotype (Table 3). However, gall morphology is different between females and males of the O. eucalypti 'Trans' biotype, with females inducing circular, protruding galls and males inducing pit galls, while galls induced by $O$. bipolaris show no differences between both sexes. The host range of $O$. bipolaris is also similar to the O. eucalypti 'Trans' biotype, which has been reported to attack Eucalyptus species in the section Transversaria and E. urophylla $[13,15]$. However, one of the host plants of O. bipolaris, E. tereticornis, is in the Dumaria section of Eucalyptus.

The reproduction modes are different among Ophelimus species, but all seem to be female-biased. The O. eucalypti 'Maid' biotype [24], O. maskelli [14] and O. mediterraneus [9] have been reported as thelytokous that reproduce females only. According to Withers et al. [13], the O. eucalypti 'Trans' biotype is biparental, but the sex ratio was not clearly stated in their study, although Dittrich-Schröder et al. [15] erroneously claimed that the lineage was male-biased when citing Withers et al.'s study. Ophelimus migdnorum is also 
biparental, and $58.9 \%$ are females [10]. Our study indicates that O. bipolaris is female-biased, with about $97.2 \%$ of the collected specimens being females. Female-biased sex ratio occurs frequently in Chalcidoidea, and it has been associated with infection by symbiotic bacteria able to manipulate the reproduction of their host [25]. Sex ratio variations might reflect the infection by different bacterial endosymbionts, resulting in different reproduction modes of the hosts and therefore different species lineages. For example, molecular analyses suggested that $L$. invasa is in fact a complex of two cryptic species that are infected by two closely related strains of Rickettsia [7]. Therefore, screening for the infection of endosymbionts among Ophelimus species, especially the two biotypes of O. eucalypti and O. bipolaris, is a possible direction in clarifying the identities of these species.

Both the $28 \mathrm{~S}$ and $\mathrm{COI}$ sequences showed unambiguous differentiation between O. bipolaris and four other species (Figures 3 and 4), although the $28 S$ sequences of O. bipolaris and the O. eucalypti 'Trans' biotype are 99.3-99.5\% identical, and one might suspect that O. bipolaris is conspecific with the O. eucalypti 'Trans' biotype. However, the $28 \mathrm{~S}$ is conserved and often invariant between closely related species in Eulophidae [26,27]. The low distance of the $28 \mathrm{~S}$ sequences among Ophelimus species is consistent with what already observed in Eulophidae $[9,28]$. While the divergence of $C O I$ sequences is high between O. bipolaris and other studied Ophelimus species, most of the COI sequences are identical among the specimens collected from all the four studied localities. Even the two sequences have only two different nucleotides. This reduced genetic COI variation could be due to founder effects (the reduction in genetic variation that results when a small subset of a large population is used to establish a new colony) [29] or endosymbiont infection (endosymbionts can act as reproductive manipulators and are considered responsible for the low mitochondrial genetic diversity in infected populations) [30,31]. Further studies are required to investigate the cause of this low mitochondrial genetic diversity.

The result of the morphological analysis (Table 3) was also consistent with the molecular results, indicating $O$. bipolaris is a distinct species. The number of setae on the submarginal vein of the fore wing was first thought be an important diagnostic character for Ophelimus species [14,32], at least $O$. maskelli was thought to be the only species with one single submarginal vein seta, but subsequent studies showed that this character was, however, not discriminant among Ophelimus species [9,10]. According to Molina-Mercader et al. [10], the number of submarginal vein setae is in accordance with the body size of the specimen. Ophelimus bipolaris has 3-5 submarginal vein setae, and we indeed found that smaller specimens tend to have fewer setae (Table S4). Body size was used in the key compiled by Borowiec et al. [9], but apparently this character is also not discriminant among Ophelimus species. Besides, body size is easily affected by temperature and the host plant species [33]. Nevertheless, O. eucalypti is the largest species recorded, and O. bipolaris is relatively smaller. Body color seems to be useful in separating O. bipolaris (head and mesosoma are metallic green) from $O$. eucalypti (head and mesosoma mainly black and only faintly tinged with metallic green or purplish). The following characters might be of diagnostic value: (1) the postmarginal vein is much shorter than stigmal vein; (2) the mesoscutal midlobe with 5 pairs of long setae; (3) the propodeum is distinctly longer than metascutellum medially.

Our preliminary observation showed that O. bipolaris on E. urophylla only took approximately 2 months to complete a life cycle in Guangzhou, under local climatic conditions (temperature: $23.5-30^{\circ} \mathrm{C}$ ). Obviously, its life cycle might be affected by temperature and host plant species, as has been found in O. maskelli [14]. Further studies regarding the host range and life cycle of $O$. bipolaris in China are required.

The origin of O. bipolaris is unknown, but undoubtedly it originates from Australia or Indonesia, since it exclusively attacks Eucalyptus species. Of its four known host plant species or hybrids, E. tereticornis and E. tereticornis are native to Australia, while E. urophylla is native to Indonesia. Therefore, O. bipolaris is an invasive species in China. As mentioned above, the low mitochondrial genetic diversity may be due to founder effects, and it may suggest that this is a recent invasion in China. Considering the severe damage and 
economic loss of Eucalyptus have been caused by the invasive species of Ophelimus outside their native ranges $[9,10,13,14,34]$, eradication or control strategies against $O$. bipolaris is urgently needed in China.

\section{Conclusions}

Based on the result of analyzing the biological, morphological and molecular evidence, we have formally described a new invasive species of the Eucalyptus gall wasp, Ophelimus bipolaris Chen \& Yao, which represents the first species of the genus present in China. This wasp induces protruding galls only on the leaf blade of Eucalytpus. Its host plants at least include E. grandis, E. grandis $\times$ E. urophylla, E. tereticornis and E. urophylla in China. Our preliminary observation showed that $O$. bipolaris can complete a life cycle on E. urophylla in approximately 2 months under local climatic conditions. Further studies on the life cycle, host range, geographical distribution, economical damage and management of this wasp are urgently needed in China and possible distributed countries.

Supplementary Materials: The following are available online at https: / www.mdpi.com/article/ 10.3390/insects12090778/s1. Figure S1. Average temperatures of Guangzhou from April to July, 2021. (Data from China Meteorological Data Service Center). Figure S2. Rhicnopeltella eucalyptis Gahan, holotype, female A Habitus, dorsal view B Habitus, lateral view C Head and mesosoma, dorsal view D Head and mesosoma, lateral view E Head, anterior view F Wings. (Images are used with permission from NMNH). Table S1. Details of the sampling, host plant and number of wasps collected. Table S2. Interspecific pairwise distance of Ophelimus species based on $28 \mathrm{~S}$ sequences (\%). Table S3. Interspecific pairwise distance of Ophelimus species based on COI sequences (\%); Table S4. Summarized data of body measurements (in $\mathrm{mm}$ ) and best ratios of O. bipolaris.

Author Contributions: Conceptualization, H.-Y.C., J.-M.Y. and H.P.; methodology, H.-Y.C. and J.M.Y.; investigation, H.-Y.C., J.-M.Y. and S.-B.H.; writing-original draft preparation, H.-Y.C. and J.-M.Y.; writing—review and editing, H.-Y.C., J.-M.Y., S.-B.H. and H.P.; supervision, H.P.; funding acquisition, H.P. All authors have read and agreed to the published version of the manuscript.

Funding: This study is supported by the Science and Technology Planning Project of Guangzhou, China (Grant No. 201904020041) and the National Animal Collection Resource Center, China.

Institutional Review Board Statement: Not applicable.

Informed Consent Statement: Not applicable.

Data Availability Statement: The data of the research were deposited in the Museum of Biology at Sun Yat-sen University (SYSBM), Guangzhou, China.

Acknowledgments: We would like to acknowledge our colleagues who assisted us with the collection of the specimens in the present paper. We wish to thank the National Museum of Natural History (NMNH) for kindly providing the images of the holotype of Rhicnopeltella eucalyptis Gahan. We are grateful to the three anonymous reviewers who greatly contributed to the improvement of this paper.

Conflicts of Interest: The authors declare no conflict of interest. The funders had no role in the design of the study; in the collection, analyses, or interpretation of data; in the writing of the manuscript, or in the decision to publish the results.

\section{References}

1. Ciesla, V.M. The role of human activities on forest insect outbreaks worldwide. Int. For. Rev. 2015, 17, 269-281. [CrossRef]

2. Wang, H.; Jiang, Z.; Yan, H. Australian tress in China. In Proceedings of the Australian Tree Species Research in China, Zhangzhou, China, 2-5 November 1992; Brown, A.G., Ed.; Australian Centre or International Agricultural Research: Canberra, Australia, 1994; pp. 19-25.

3. Arnold, R.J.; Xie, Y.J.; Luo, J.Z.; Wang, H.R.; Midgley, S.J. A tale of two genera: Exotic Eucalyptus and Acacia species in China. 2. Plantation resource development. Int. For. Rev. 2020, 22, 153-168.

4. Xie, Y.; Arnold, R.J.; Wu, Z.; Chen, S.; Du, A.; Luo, J. Advances in eucalypt research in China. Front. Agric. Sci. Eng. 2017, 4, 380-390. [CrossRef]

5. Cai, S.P.; Zeng, L.Q.; Lin, H.Z.; Lin, X.B.; Song, H.T.; Yin, L.Q.; Huang, S.J. Five defoliators on Ecualypts in China. Fujianlinye 2020, 3, 28-32+48. 
6. Tang, C.; Wan, X.J.; Wan, F.H.; Ren, S.X.; Peng, Z.Q. The blue gum chalcid, Leptocybe invasa, invaded Hainan province. Chin. J. Entomol. 2008, 45, 967-971.

7. Nugnes, F.; Gebiola, M.; Monti, M.M.; Gualtieri, L.; Giorgini, M.; Wang, J.; Bernardo, U. Genetic diversity of the invasive gall wasp Leptocybe invasa (Hymenoptera: Eulophidae) and of its Rickettsia endosymbiont, and associated sex-ratio differences. PLoS ONE 2015, 10, e0124660.

8. Mendel, Z.; Protasov, A.; Fisher, N.; La Salle, J. Taxonomy and biology of Leptocybe invasa gen. \& sp. n. (Hymenoptera: Eulophidae), an invasive gall inducer on Eucalyptus. Aust. J. Entomol. 2004, 43, 101-113.

9. Borowiec, N.; La Salle, J.; Brancaccio, L.; Thaon, M.; Warot, S.; Branco, M.; Ris, N.; Malausa, J.C.; Burks, R. Ophelimus mediterraneus sp. n. (Hymenoptera, Eulophidae): A new Eucalyptus gall wasp in the Mediterranean region. Bull. Entomol. Res. 2019, 109, 678-694. [CrossRef]

10. Molina-Mercader, G.; Angulo, A.O.; Olivares, T.S.; Sanfuentes, E.; Castillo-Salazar, M.; Rojas, E.; Toro-Núñez, O.; Benítez, H.A.; Hasbún, R. Ophelimus migdanorum Molina-Mercader sp. nov. (Hymenoptera: Eulophidae): Application of Integrative Taxonomy for Disentangling a Polyphenism Case in Eucalyptus globulus Labill Forest in Chile. Forests 2019, 10, 720. [CrossRef]

11. Bouček, Z. Australasian Chalcidoidea (Hymenoptera). A Biosystematics Revision of Genera of Fourteen Families, with a Reclassification of Species; CAB International: Wallingford, UK, 1988.

12. La Salle, J. Biology of gall inducers and evolution of gall induction in Chalcidoidea (Hymenoptera: Eulophidae, Eurytomidae, Pteromalidae, Tanaostigmatidae, Torymidae). In Biology, Ecology and Evolution of Gall-Inducing Arthropods; Raman, A., Schaefer, C.W., Withers, T.M., Eds.; Science Publishers: Enfield, UK, 2005; Volume 2, pp. 503-533.

13. Withers, T.M.; Raman, A.; Berry, J.A. Host range and biology of Ophelimus eucalypti (Gahan) (Hym.: Eulophidae), a pest of New Zealand eucalypts. N. Z. Plant Prot. 2000, 53, 339-344.

14. Protasov, A.; La Salle, J.; Blumberg, D.; Brand, D.; Saphir, N.; Assael, F.; Fisher, N.; Mendel, Z. Biology, revised taxonomy and impact on host plants of Ophelimus maskelli, an invasive gall inducer on Eucalyptus spp. in the Mediterranean area. Phytoparasitica 2007, 25, 50-76. [CrossRef]

15. Dittrich-Schröder, G.; Hurley, B.P.; Wingfield, M.J.; Nahrung, H.F.; Slippers, B. Invasive gall-forming wasps that threaten non-native plantation-grown Eucalyptus: Diversity and invasion patterns. Agric. For. Entomol. 2020, 22, 285-297. [CrossRef]

16. Gahan, A.B. A list of phytophagous Chalcidoidea with descriptions of two new species. Proc. Entomol. Soc. Wash. 1922, 24, 33-58.

17. Mendel, Z.; Protasov, A.; Blumberg, D.; Brand, D.; Saphir, N.; Madar, Z.; La Salle, J. Release and recovery of parasitoids of the Eucalyptus gall wasp Ophelimus maskelli in Israel. Phytoparasitica 2007, 35, 330-332. [CrossRef]

18. Gibson, G.A.P.; Huber, J.T.; Woolley, J.B. Annotated Keys to the Genera of Nearctic Chalcidoidea (Hymenoptera); NRC Research Press: Ottawa, ON, Canada, 1997.

19. Taekul, C.; Valerio, A.A.; Austin, A.D.; Klompen, H.; Johnson, N.F. Molecular phylogeny of telenomine egg parasitoids (Hymenoptera: Platygastridae s.l.: Telenominae): Evolution of host shifts and implications for classification. Syst. Entomol. 2014, 39, 24-35. [CrossRef]

20. Folmer, O.; Black, M.; Hoeh, W.; Lutz, R.; Vrijenhoek, R. DNA primers for amplification of mitochondrial cytochrome c oxidase subunit I from diverse metazoan invertebrates. Mol. Mar. Biol. Biotechnol. 1994, 3, 294-299.

21. Gillespie, J.J.; Munro, J.B.; Heraty, J.M.; Yoder, M.J.; Owen, A.K.; Carmichael, A.E. A Secondary Structural Model of the 28S rRNA Expansion Segments D2 and D3 for Chalcidoid Wasps (Hymenoptera: Chalcidoidea). Mol. Biol. Evol. 2005, 22, 1593-1608. [CrossRef]

22. Katoh, K.; Standley, D.M. MAFFT multiple sequence alignment software version 7: Improvements in performance and usability. Mol. Biol. Evol. 2013, 30, 772-780. [CrossRef]

23. McLaren, P. Ophelimus eucalypti: A recently introduced gall-making insect on eucalypts. Tree Grower May 1989, $10,26-27$.

24. Clark, A.F. A survey of the insect pests of eucalypts in New Zealand. NZ J. Sci. Tech. 1938, 19, 750-761.

25. Heimpel, G.E.; de Boer, J.G. Sex determination in the Hymenoptera. Annu. Rev. Entomol. 2008, 53, 209-230. [CrossRef] [PubMed]

26. Heraty, J.M.; Woolley, J.B.; Hopper, K.R.; Hawks, D.L.; Kim, J.W.; Buffington, M. Molecular phylogenetics and reproductive incompatibility in a complex of cryptic species of aphid parasitoids. Mol. Phylogenet. Evol. 2007, 45, 480-493. [CrossRef] [PubMed]

27. Gebiola, M.; Bernardo, U.; Burks, R. A reevaluation of the generic limits of Pnigalio Schrank (Hymenoptera: Eulophidae) based on molecular and morphological evidence. Zootaxa 2010, 2484, 35-44. [CrossRef]

28. Gebiola, M.; Bernardo, U.; Monti, M.M.; Navone, P.; Viggiani, G. Pnigalio agraules (Walker) and Pnigalio mediterraneus Ferrière and Delucchi (Hymenoptera: Eulophidae): Two closely related valid species. J. Nat. Hist. 2009, 43, 2465-2480. [CrossRef]

29. Dlugosch, K.M.; Parker, I.M. Founding events in species invasions: Genetic variation, adaptive evolution, and the role of multiple introductions. Mol. Ecol. 2008, 17, 431-449. [CrossRef]

30. Johnstone, R.A.; Hurst, G.D. Maternally inherited male-killing microorganisms may confound interpretation of mitochondrial DNA variability. Biol. J. Linn. Soc. 1996, 58, 453-470. [CrossRef]

31. Gueguen, G.; Vavre, F.; Gnankine, O.; Peterschmitt, M.; Charif, D.; Chiel, E.; Gottlieb, Y.; Ghanim, M.; Zchori-Fein, E.; Fleury, F. Endosymbiont metacommunities, mtDNA diversity and the evolution of the Bemisia tabaci (Hemiptera: Aleyrodidae) species complex. Mol. Ecol. 2010, 19, 4365-4378. [CrossRef]

32. Burks, R.A.; Mottern, J.L.; Waterworth, R.; Paine, T.D. First report of the Eucalyptus gall wasp, Ophelimus maskelli (Hymenoptera: Eulophidae), an invasive pest on Eucalyptus, from the Western Hemisphere. Zootaxa 2015, 3926, 448-450. [CrossRef] 
33. Colinet, H.; Boivin, G.; Hance, T. Manipulation of parasitoid size using the temperature-size rule: Fitness consequences. Oecologia 2007, 152, 425-433. [CrossRef]

34. Garcia, A.; Goncalves, H.; Borowiec, N.; Franco, J.C.; Branco, M. Ophelimus sp., a new invasive gall wasp of Eucalyptus globulus in Europe, escapes the parasitism by Closterocerus chamaeleon due to an asynchronous life cycle. Biol. Control. 2019, 131, 1-7. [CrossRef] 